
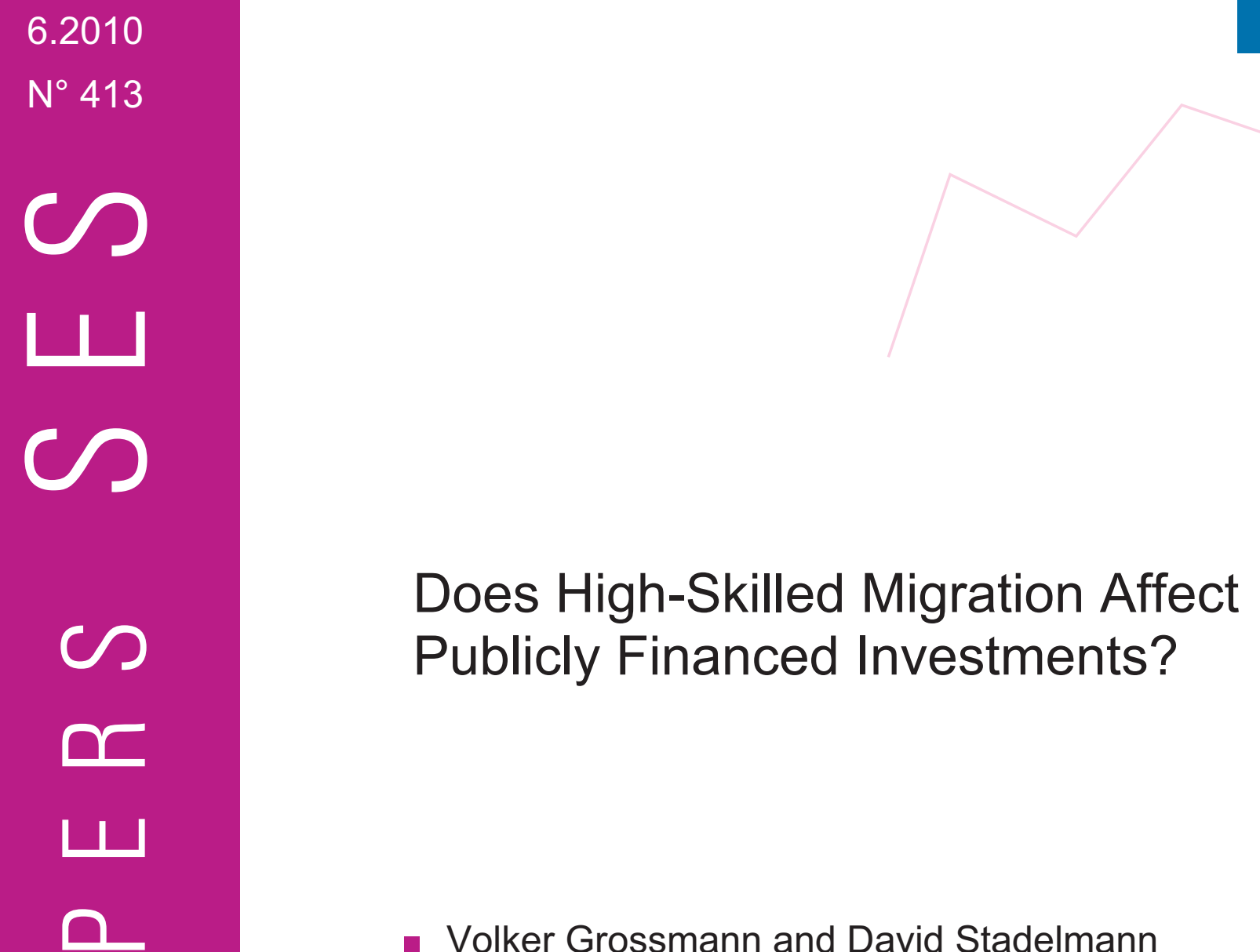

- Volker Grossmann and David Stadelmann
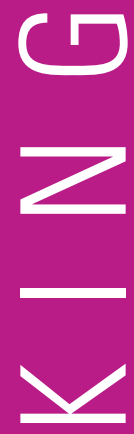

๘

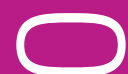

Faculté des Sciences Economidues et Sociales Wirtschafts- und Sozialwissenschaftliche Fakultät Université de Fribourg | Universität Freiburg 


\title{
Does High-Skilled Migration Affect Publicly Financed Investments?*
}

\author{
Volker Grossmann ${ }^{\dagger}$ and David Stadelmann ${ }^{\ddagger}$
}

October 14, 2009

\begin{abstract}
This paper analyzes the interaction between migration of high-skilled labor and publicly financed investment. We develop a theoretical model with multiple, ex ante identical jurisdictions where individuals decide on education and subsequent emigration. Migration decisions are based on differences in net income across jurisdictions which endogenously may occur. The interaction between income differences and migration flows gives rise to the potential of multiple equilibria: a symmetric equilibrium without migration and an asymmetric equilibrium in which net income levels differ among jurisdictions and trigger migration flows. In the former equilibrium, all jurisdictions have the same public investment level. In the latter one, public investment is high in host economies of skilled expatriates and low in source economies. We empirically test the hypothesis that emigration rates are negatively associated with various kinds of publicly financed investment levels for OECD countries.
\end{abstract}

Key words: High-skilled migration; Human capital externalities; Publicly financed investment.

JEL classification: F22; H40.

${ }^{*}$ We are grateful to Michel Beine, Tomer Blumkin, Barry R. Chiswick, Hartmunt Egger, and Hillel Rapoport for comments and suggestions on an earlier draft. We also benefited from discussion with seminar participants at the University of Zurich, University of Geneva, University of Fribourg, the Annual Meeting of the European Economic Association 2008 in Milan, and the Annual Meeting of the German Economic Association in Magdeburg.

${ }^{\dagger}$ University of Fribourg; CESifo, Munich; and Institute for the Study of Labor (IZA), Bonn. Postal adress: University of Fribourg, Departement of Economics, Bd. de Pérolles 90, G424, 1700 Fribourg, Switzerland. Tel.: +41 (026) 3009383. Email: volker.grossmann@unifr.ch

${ }^{\ddagger}$ University of Fribourg, Departement of Economics, Bd. de Pérolles 90, F410, 1700 Fribourg, Switzerland. Tel.: +41 (026) 3009382. Email: david.stadelmann@unifr.ch 


\section{Introduction}

Governments have become increasingly aware of international factor mobility when designing public policy. In recent times movements of workers with high education levels have provoked an intensive debate among policymakers in advanced countries (e.g. Congressional Budget Office, 2005; Council of Europe, 1995; European Commission, 2003, 2007). Anglo-Saxon countries have developed successful strategies to attract high-skilled labor, ${ }^{1}$ while many other regions, even advanced countries in Europe, suffer from significant brain drain. For instance, the stock of expatriates of the tertiary educated from Finland, Portugal and Italy around the year 2000 amounted to a non-negligible figure of 7.2, 18.9 and 9.6 percent of educated residents, respectively (Doquier and Marfouk, 2006). Among French, Spanish and Italian expatriates arriving in the US between 1990 and 2000 around 9 percent held a Ph.D (Saint-Paul, 2004).

This paper examines the relationship between migration of skilled labor and public investment expenditure. The particular interest in this link stems from the empirically well-supported notion that brain drain is largely triggered by low earning prospects at home, and may further reduce income levels, whereas publicly financed investments may increase output capacity and therefore boost economic prosperity. Prima facie, one may therefore suspect that economies experiencing outflows of skilled labor are particularly prone to invest in public infrastructure in order to mitigate or reverse brain drain.

However, a first look at the data reveals that public investment levels in countries which benefit from high net immigration such as the US and Switzerland are comparatively high, whereas public investment in countries which suffer from high net emigration like Portugal and Mexico is comparatively low. In fact, as Figure 1a shows, in the year 2000 , net emigration rates of the tertiary educated are negatively related to $(\log )$ per capita public investment levels among OECD countries. Figure 1b considers the relationship of the changes of the two variables between 1990 and 2000 in order to net out omitted variables which are constant over time. It again suggests a negative relationship,

\footnotetext{
${ }^{1}$ According to Doquier and Marfouk (2006), almost 4/5 of the over 20 million tertiary educated migrants lived in Anglo-Saxon countries in the year 2000. 11.7 percent of all doctorate holders in the US were foreign citizens in 2004 and 25.7 percent of the doctorate holders (368,800 people) were foreign born (Auriol, 2007).
} 
which means that a larger migration outflow is associated with slower growth of public investment expenditure.

\section{$<$ Figure 1 $>$}

To understand these empirical patterns, we develop a theoretical model with many ex ante identical jurisdictions. We examine how migration flows interact with public investment levels set by benevolent policymakers. Source and host economies of high-skilled expatriates can endogenously emerge despite symmetry ex ante, which has implications for the pattern of public investment choices. There are three key features of the model. First, migration decisions are based on differences in net wage rates for the skilled across jurisdictions. $^{2}$ The possibility of migration is taken into account when the education decision is made. Second, not only do income differences trigger migration outflows, but also does higher emigration raise income gaps to host economies of skilled expatriates. This is implied by assuming human capital externalities on productivity like in Lucas (1988). Such externalities give rise to the possibility of multiple equilibria: that is, in addition to an equilibrium without migration, there may be migration flows between ex ante identical economies. Third, we assume that higher public investments are productivity-enhancing and thus raise income per capita.

We show that, as a consequence of these basic premises and consistent with Figure 1 , it is optimal for host economies to have higher public investment levels than source economies. Interestingly, according to our model, welfare-maximization is equivalent to minimization of brain drain in a source economy. Our analysis therefore suggests that it is optimal for source economies to adjust the public investment level in order to mitigate the brain drain problem. However, it is a low rather than a high spending level, compared to host economies, which achieves this goal. In host economies it is optimal to set public investment expenditure at a level which maximizes the number of high-skilled immigrants.

In order to establish that the relationships in Figure 1 represent causal effects, in our empirical analysis, we construct an instrument for the aggregate net emigration rate of a

\footnotetext{
${ }^{2}$ See Beine, Doquier and Ozden (2008) and Grogger and Hanson (2008) for recent empirical support.
} 
country's skilled workers. The instrumentation strategy is motivated by the innovative way to predict of aggregate trade flows in the widely cited contribution of Frankel and Romer (1999) on the effects of trade on growth. We regress bilateral emigration stocks of tertiary educated workers on several presumably exogenous factors (like the distance between countries). We then use the predicted bilateral stocks to construct an aggregate net emigration rate for each country. The instrumental variable (IV) estimates largely confirm results from OLS estimations.

Our contribution shares several features with the previous literature. For instance, as in our model, Miyagiwa (1991) and Grossmann and Stadelmann (2008) allow for socially increasing returns to scale. Emigration therefore potentially reduces wages for the skilled. However, these studies assume that income of the host economy is exogenous. In our framework, both emigration patterns and income levels are fully endogenous. This enables us to derive asymmetry of ex ante identical economies as a result of increasing returns. Second, similar to seminal papers like Bhagwati and Hamada (1974), albeit for different reasons, our framework emphasizes adverse effects of outward migration (and beneficial ones for host economies). This is not to deny the possibility of potentially beneficial effects of emigration for source economies. These may arise in low-income countries from higher incentives to acquire human capital as response to higher immigration quotas in rich countries (e.g., Mountford, 1997; Stark, Helmenstein and Prskawetz, 1997, 1998; Beine, Doquier and Rapoport, 2001). However, empirically, this mechanism is supported only for poor countries with rather low levels of human capital (Beine, Doquier and Rapoport, 2001, 2008). We instead focus on ex ante similar economies in the theoretical part and provide evidence for OECD countries, where positive effects of brain drain are unlikely to occur. Finally, our research is related to the by now large literature on the consequences of high-skilled labor mobility on the public sector. Many studies focussed on the positive and normative implications of brain drain for the tax system (e.g. Bhagwati and Wilson, 1989; Wildasin, 2000; Andersson and Konrad, 2003; Bucovetsky, 2003; Wilson, 2008). Other contributions dealt with the implications of declining mobility costs for public education finance (see e.g. Justman and Thisse, 1997, 2000; Poutvaara, 2004, 2008; Egger, Falkinger and Grossmann, 2007). Our paper has a differ- 
ent focus. Rather than analyzing fiscal competition or socially desirable taxation, ${ }^{3}$ we develop the theoretical hypothesis that a negative relationship between high-skilled emigration and productive government spending endogenously arises and present empirical support for it.

The paper is structured as follows. Section 2 presents the theoretical model. Section 3 first derives the equilibrium level of migration in an economy as a function of its public investment level and of net income levels abroad. It then examines the international equilibrium, by highlighting the role of expectations for the equilibrium outcome. There we focus on the scenario where jurisdictions optimally choose their public investment levels. Section 4 presents empirical evidence on the predicted relationship between migration patterns and public investment levels by distinguishing various categories of potentially productivity-enhancing public expenditures. The last section concludes.

\section{The Model}

Consider a continuum of ex ante identical jurisdictions with unit mass. Each jurisdiction is initially populated by a unit mass of natives. There is perfect competition in goods and labor markets.

In each jurisdiction, there is a representative firm which produces a homogenous consumption good, chosen as numeraire. Output $Y$ is given by the linearly homogenous function $F$, specified in CES-form:

$$
Y=F(X, L)=A \cdot\left(\alpha X^{\frac{\sigma-1}{\sigma}}+(1-\alpha) L^{\frac{\sigma-1}{\sigma}}\right)^{\frac{\sigma}{\sigma-1}}
$$

$\sigma>0,0<\alpha<1$, where $L$ is employment of low-skilled labor and $X$ is the input of an intermediate capital good. Total factor productivity (TFP), $A$, depends on the number

\footnotetext{
${ }^{3}$ Technically, we abstract from fiscal competition by assuming that jusrisdictions are small and do not strategically interact.
} 
of high-skilled workers, $N$, in the economy. ${ }^{4}$ We have

$$
A=a(N)
$$

where $a(\cdot)$ is an increasing and concave function with $a(0) \geq 0$. Thus, a reduction in the skilled labor force, as result of emigration, reduces output for given input levels. ${ }^{5}$ $A$ is taken as given by the representative firm. Our formulation thus captures human capital externalities on productivity like in Lucas (1988); there are socially increasing but privately constant returns to scale.

Production of the intermediate good is skill-intensive. For simplicity it only uses high-skilled labor. Output is given by

$$
X=B \cdot S,
$$

where $S$ denotes the amount of high-skilled labor and $B$ measures its productivity. Productivity is affected by the public investment level of a jurisdiction, $G$, measured in units of the final good. We assume

$$
B=b(G)
$$

where $b(\cdot)$ is an increasing and concave function with $b(0)>0$; moreover, we assume $\lim _{G \rightarrow 0} b^{\prime}(G) \rightarrow \infty$ and $\lim _{G \rightarrow \infty} b^{\prime}(G)=0 .{ }^{6}$ According to (4), public investment $G$ is a local public good (i.e., there are no spillovers to other jurisdictions).

Public investment is financed by proportional wage taxation. The tax rate is denoted by $\tau \in(0,1)$. It applies to all workers employed in the domestic economy (natives and immigrants, but not emigrants). ${ }^{7}$

\footnotetext{
${ }^{4}$ Such "scale effect" does not necessarily mean that more largely populated economies are richer than small ones. What may matter for TFP is the density of the skilled population in an economy rather than its size. Normalizing the area of a jurisdiction to unity gives equivalently rise to formulation (2).

${ }^{5}$ In Grossmann and Stadelmann (2008), a similar property arises from a monopolistic competition model with endogenous R\&D investment decisions of intermediate good firms.

${ }^{6}$ The boundary conditions ensure an interior solution for the optimal choice of $G$ of local governments.

${ }^{7}$ The assumption is made for concreteness. Results would be unchanged if immigrants were not be obliged to pay taxes or if emigrants still had to pay taxes at home, as will become apparent.
} 
Individuals are endowed with one unit of time. They decide whether or not to become high-skilled, at cost of $e \in(0,1)$ units of time. If not spending time $e$ in school, an individual remains low-skilled. Time not used for education is inelastically supplied to a perfect labor market.

Utility of individual $i$ is given by his/her consumption level (equal to after-tax wage income) $c(i)$ of the final good when working at home. If the individual works abroad, utility is a discounted measure compared to that of non-migrants; formally, utility is given by $c(i) /(1+\theta(i)){ }^{8}$ Mobility cost parameter $\theta$ is distributed according to a continuous p.d.f. $\varphi(\theta)$ with positive support; the corresponding c.d.f. is denoted by $\Phi(\theta)$. There are no immigration quotas. When deciding whether or not to become skilled, individuals take both migration incentives and costs into account. In order to focus on migration patterns of high-skilled workers, as common in the brain drain literature, we assume that low-skilled labor is immobile. ${ }^{9}$

We close the model description with a remark on the role of public investment, $G$, for economic performance of a jurisdiction. Rather than assuming that an increase in $G$ raises productivity in the intermediate goods sector, and thus is high-skilled labor saving, one may alternatively assume that TFP $A$ in the final goods sector is positively affected by a higher $G$. It is easy to show that in this case, an increase in $G$ would leave the educational choice unaffected. In contrast, in our formulation public investment will generally affect education decisions. Using (3) in (1) we see that $\sigma$ equals the elasticity of substitution between high-skilled and low-skilled labor. Empirical evidence suggests $\sigma>1$ (e.g. Johnson, 1997; Card, 2009). As will become apparent, in this case an increase in $G$ induces more individuals to become educated. This result is consistent with empirical evidence in the case of public education spending (e.g. Egger, Egger, Falkinger and Grossmann, 2009).

\footnotetext{
${ }^{8}$ See Stark, Helmenstein and Prskawetz (1997), among others

${ }^{9}$ This could be justified by the fact that workers with lower education levels often face severe institutional migration barriers in potential host economies. Moreover, the low-skilled may be more likely to have difficulties in finding a job, learning a foreign language and integrating in the foreign society.
} 


\section{Equilibrium Analysis}

In this section, we first analyze the education and migration decision in a single jurisdiction for a given public investment level and given the income opportunities abroad (small open economy). We then examine the international equilibrium where in all jurisdictions income levels and migration flows are endogenous and public investment levels are optimally chosen.

\subsection{Small Open Economy}

We start by deriving wage rates for high- and low-skilled labor, denoted by $w_{S}$ and $w_{L}$, respectively. The wage rate per unit of high-skilled labor is given by its marginal revenue product in the intermediate goods sector, $w_{S}=p B$, where $p$ denotes the price of the intermediate good. Price $p$ is equal to the marginal product in the final goods sector (inverse demand for the intermediate good), $p=\partial Y / \partial X$. Consequently, we find

$$
w_{S}=A\left(\alpha^{\sigma} B^{\sigma-1}+(1-\alpha) \alpha^{\sigma-1} B^{\frac{(\sigma-1)^{2}}{\sigma}}\left(\frac{L}{S}\right)^{\frac{\sigma-1}{\sigma}}\right)^{\frac{1}{\sigma-1}}
$$

according to (1) and (3). Moreover, combining $w_{S}=B \cdot(\partial Y / \partial X)$ with $w_{L}=\partial Y / \partial L$ and using $X=B S$, we find

$$
\frac{w_{S}}{w_{L}}=\frac{\alpha}{1-\alpha} B^{\frac{\sigma-1}{\sigma}}\left(\frac{L}{S}\right)^{\frac{1}{\sigma}}
$$

for the relative wage rate.

In an equilibrium where at least some skilled natives remain in the domestic economy, individuals (which are ex ante identical) must be indifferent whether or not to acquire education. Thus, in view of time cost $e$, the no arbitrage condition

$$
(1-e) w_{S}=w_{L}
$$

must hold. Combining (6) and (7), we find that the ratio of low-skilled to high-skilled 
units of labor is given by

$$
\frac{L}{S}=\left(\frac{1-\alpha}{(1-e) \alpha}\right)^{\sigma} B^{1-\sigma} .
$$

Substituting (8) into (5) leads to

$$
w_{S}=A\left[\alpha^{\sigma} B^{\sigma-1}+(1-\alpha)^{\sigma}(1-e)^{1-\sigma}\right]^{\frac{1}{\sigma-1}}
$$

Thus, the wage rate per unit of high-skilled labor, $w_{S}$, is increasing in $B$. For later use, also note that in the case where $\sigma \leq 2, w_{S}$ is concave as a function of $B$.

We next derive the number of non-migrating high-skilled workers, $N$, when $m$ workers migrate. High-skilled labor input at home is given by $S=(1-e) N$. Combining this with (8), we obtain $L=\left(\frac{1-\alpha}{(1-e) \alpha}\right)^{\sigma} B^{1-\sigma}(1-e) N$. Substituting the latter expression into resource constraint $N+m+L=1$ and solving for $N$ leads to

$$
N=\frac{1-m}{1+\left(\frac{1-\alpha}{\alpha}\right)^{\sigma}[(1-e) B]^{1-\sigma}} .
$$

Hence, under optimal education decisions, an increase in the number of emigrants $m$ lowers the number of high-skilled workers remaining in the economy, whereas the total number of natives who choose to acquire education, $N+m$, rises. Moreover, higher productivity $B=b(G)$, which may be triggered by an increase in the public investment level, $G$, raises the number of high-skilled workers in the domestic economy, $N$, if and only if $\sigma>1$. As pointed out at the end of section $2, \sigma>1$ is the empirically relevant case. Also note that in the case where $\sigma \leq 2, N$ is strictly concave as a function of $B$. Throughout we maintain the assumption

$$
1<\sigma \leq 2
$$

which corresponds to the range for the elasticity of substitution between high-skilled and low-skilled labor found in the literature. 
Combining $A=a(N)$ with (10) and substituting into (9) leads to

$$
w_{S}=a\left(\frac{1-m}{1+\left(\frac{1-\alpha}{\alpha}\right)^{\sigma}[(1-e) B]^{1-\sigma}}\right)\left[\alpha^{\sigma} B^{\sigma-1}+(1-\alpha)^{\sigma}(1-e)^{1-\sigma}\right]^{\frac{1}{\sigma-1}} \equiv \tilde{w}^{S}(B, m) .
$$

Hence, $\tilde{w}^{S}(B, m)$ is increasing and strictly concave as a function of $B$ under assumption A1 $\left(\tilde{w}_{B}^{S}>0, \tilde{w}_{B B}^{S}<0\right) . \quad \sigma>1$ is also sufficient (but not necessary) for the crossderivative of $\tilde{w}^{S}$ to be negative $\left(\tilde{w}_{B m}^{S}<0\right)$. This will turn out to be a key property of the model. It may be understood as follows: Due to human capital externalities, higher emigration lowers TFP and therefore reduces wage rates; in particular, $\tilde{w}_{m}^{S}<0$. The decline in TFP lowers the marginal product of the intermediate good in final goods production; thus, an increase in the productivity of skilled labor $B$ has a lower impact on wage rates if $m$ increases. As $B$ is positively affected by a higher public investment level $G$, this implies that an increase in $G$ has a lower impact on wage rates, if more skilled workers emigrate.

We now turn to the migration decision. Let the highest net wage rate per unit of high-skilled labor among jurisdictions abroad be given by $\bar{w}_{n e t}^{S}$. For the purpose of this subsection, we treat $\bar{w}_{n e t}^{S}$ as exogenous whereas in an international equilibrium analyzed below, wages everywhere are affected by migration flows.

In view of disutility from emigrating for a given consumption level, individual $i$ emigrates if

$$
\frac{\bar{w}_{n e t}^{S}}{w_{n e t}^{S}} \geq 1+\theta(i)
$$

where $w_{n e t}^{S} \equiv(1-\tau) w_{S}$ is the after-tax wage rate of skilled labor in the considered economy. Thus, if $w_{n e t}^{S}<\bar{w}_{n e t}^{S}$, the number of emigrants is

$$
m=\int_{0}^{\bar{w}_{n e t}^{S} / w_{n e t}^{S}-1} \varphi(\theta) \mathrm{d} \theta=\Phi\left(\bar{w}_{n e t}^{S} / w_{n e t}^{S}-1\right)
$$

From the government budget constraint, $\tau\left[w_{S}(1-e) N+w_{L} L\right]=G$. Employing no arbitrage condition $(1-e) w_{S}=w_{L}$ and resource constraint $N+L=1-m$, we find that 
$\tau w_{S}=\frac{G}{(1-m)(1-e)}$. Thus, we have

$$
w_{n e t}^{S}=w^{S}-\tau w^{S}=\tilde{w}^{S}(b(G), m)-\frac{G}{(1-m)(1-e)} \equiv W(G, m) .
$$

From the properties of (11) and function $b$, the net wage rate $w_{n e t}^{S}=W(G, m)$ is decreasing in the number of emigrants $m$, for two reasons. The first reason is that an increase in $m$ lowers TFP, as discussed above. The second reason is that higher emigration reduces the tax base, which means that for a given public investment level $G$, the tax rate $\tau$ has to increase in order to balance the government budget. Both effects go in the same direction. If we alternatively assumed that emigrants still pay taxes where they are born, such that the second effects would vanish, $W_{m}<0$ would still hold.

There are two further interesting properties of function $W$, which give rise to our main results, as will become apparent. First, under assumption A1, after-tax wages are strictly concave as a function of $G, W_{G G}<0 .{ }^{10}$ Second, the effect of an increase in $G$ on wages is smaller, if emigration is higher; formally, $W_{G m}<0$. The property also arises for two reasons: First, as discussed, pre-tax wage rates are rising less as a response of an increase in productivity parameter $B$ when $m$ increases (recall $\tilde{w}_{B m}^{S}<0$ ). Moreover, it holds that the additional tax burden of an increase in $G$ is higher, if emigration rises. Again the second effect would vanish if emigrants still paid taxes in the economy where they are born.

According to (13), if $\bar{w}_{n e t}^{S} \geq W(G, m)$, the number of emigrants $m \geq 0$ is implicitly given by

$$
m=\Phi\left(\frac{\bar{w}_{n e t}^{S}}{W(G, m)}-1\right) \equiv R H S .
$$

Figure 2 depicts the right-hand side, $R H S$, of (15), as a $(\mathcal{S}$-shaped) function of $m$ (given $\bar{w}_{n e t}^{S}$ and $\left.G\right)$. An equilibrium is reached if $R H S$ intersects with the 45-degree line. Figure 2 shows three equilibria, with migration levels denoted by $m_{0}, m$ ' and $m_{1}$. Multiple equilibria easily arise due to the following interaction: on the one hand, (after-tax) income differences trigger migration flows. On the other hand, higher emigration triggers income reductions in the source economy, due to negative human capital externalities of

\footnotetext{
${ }^{10}$ Recall that $\tilde{w}_{B B}^{S}<0$ and $b^{\prime \prime} \leq 0$.
} 
brain drain; this gives further incentives to emigrate. Consequently, either emigration and the wage gap to the exogenous level $\bar{w}_{n e t}^{S}$ are high or both are low. Figure 2 is drawn in such a way that at $m_{0}=0$ (no emigration or immigration in the considered economy) the net wage rate is the same as the highest one abroad, $W(G, 0)=\bar{w}_{n e t}^{S}$. The two other equilibria in Figure 2, $m^{\prime}$ and $m_{1}$, feature emigration.

\section{$<$ Figure 2 $>$}

Throughout, we invoke the standard notion of tâtonnement stability; here, this means that we focus on migration levels where small perturbations of an equilibrium gives rise to a tendency of $m$ to return to its initial level. In Figure 2, this is the case when $R H S$ crosses the 45-degree line from above (i.e., $\partial R H S / \partial m<1$ ). Thus, $m_{0}=0$ and $m_{1}$ are stable equilibrium migration levels, whereas at $m$ ' the equilibrium is unstable. For instance, suppose that the number of emigrants $m$ would be slightly below $m_{1}$. In this case, $R H S>m$, implying that emigration tends to rise. If to the contrary the number of emigrants $m$ is slightly higher than $m_{1}$, then $R H S<m$ and the number of migrants tends to fall. The opposite holds at $m$ '.

\subsection{International Equilibrium}

We now turn to the international equilibrium, where all income levels are endogenous. Such an equilibrium could be analyzed for any given distribution of (local) public investment levels in the world economy. We focus on the particular case where all jurisdictions choose their public investment levels "optimally". ${ }^{11}$ As we are interested in the relationship between public investment and the pattern of migration, we need a plausible government objective function. In our context, with ex ante identical individuals, a plausible candidate is the utility of non-migrating individuals. These most plausibly represent the median voter. For a jurisdiction which does not expect to have immigration, $m \geq 0$, this means that net wage rate $W(G, m)$ is maximized subject to the

\footnotetext{
${ }^{11}$ Although this may not literally be the case, focussing on optimal choices is meaningful to explain empirical evidence if the basic economic trade-offs faced by governments, which we identify here, are taken into account in real life.
} 
education and migration decisions as reflected by (15). The after-tax wage rates abroad are taken as given. ${ }^{12}$

So far we focused on emigration. Regarding immigration, suppose a jurisdiction expecting an inflow of skilled workers takes into account that the number of immigrants, $I$, depends on the domestic net wage rate of high-skilled labor and the income opportunities of high-skilled labor abroad. Formally, suppose host economies with $I>0$ immigrants take into account schedule $I=\tilde{I}\left(w_{n e t}^{S}\right)$, with $\tilde{I}^{\prime}>0$ (i.e., higher after-tax wage rates at home makes host economies more attractive). ${ }^{13}$ Analogously to the derivation of (14), it is immediate that $w_{n e t}^{S}=W(G,-I)$. Thus,

$$
I=\tilde{I}(W(G,-I))
$$

implicitly defines the immigration level $I$ as a function of $G$; we denote this level by $I=\hat{I}(G)$. Fortunately, as will become apparent, we do not have to know functions $\tilde{I}$ or $\hat{I}$ to characterize an international (perfect foresight) equilibrium.

We require the following equilibrium conditions to hold:

- Individuals optimally choose whether to acquire education and whether to migrate if educated, by taking wage rates at home and abroad as given.

- Representative firms in both the final goods sector and the intermediate goods sector maximize profits by taking factor prices as given.

- In all jurisdictions, public investment levels are chosen such that net wage rates of the non-migrants are maximized, taking into account educational choices, migration behavior, choices of firms, and taking as given wage rates abroad.

- Migration patterns are tâtonnement-stable.

- The number of immigrants in the world equals the number of emigrants.

\footnotetext{
${ }^{12}$ Note that there is no strategic interaction in choosing public investment levels as each jurisdiction is infinitesimally small.

${ }^{13}$ The immigration level also depends on income opportunities abroad, which are suppressed in the formal representation.
} 
We will now show that, despite symmetry of jurisdictions ex ante, there may exist an equilibrium where there is a group of host economies which have the same immigration level $I$ and a group of source economies which have the same emigration level $m$. Denoting the fraction of host economies by $\lambda$, we then have

$$
\lambda I=(1-\lambda) m
$$

What agents take as given must of course be correct ex post. For governments, this includes the expectation whether to be a host or source economy of migrating workers. Expecting $m=0$, a jurisdiction solves $\max _{G} W(G, 0)$. As $W_{G G}<0$, this leads to optimal public investment level $G_{0}$ as given by $W_{G}\left(G_{0}, 0\right)=0$. Moreover, expecting $m>0$, a jurisdiction solves $\max _{G} W(G, \hat{m}(G))$, where $\hat{m}$ denotes the level of emigration which is implicitly given by (15). ${ }^{14}$ The first-order condition reads

$$
W_{G}+W_{m} \hat{m}_{G}=0 .
$$

Applying the implicit function theorem to (15) implies that

$$
\hat{m}_{G}(G)=-\frac{\varphi\left(\frac{\bar{w}_{n e t}^{S}}{W(G, \hat{m})}-1\right) \frac{\bar{w}_{n e t}^{S}}{W(G, \hat{m})^{2}} W_{G}(G, \hat{m})}{1-[\partial R H S / \partial m]_{m=\hat{m}}} .
$$

Thus, under stability $(\partial R H S / \partial m<1)$, the first order condition (18) can be rewritten as $W_{G}(G, \hat{m}(G))=0$. At the so-defined public investment level, we have $\hat{m}_{G}=0$, according to (19). Thus, $W_{G G}<0$ is sufficient for the second-order condition to hold. Finally, expecting $I=\hat{I}(G)>0$, a jurisdiction solves $\max _{G} W(G,-\hat{I}(G)) .{ }^{15}$ The firstorder condition reads

$$
W_{G}-W_{m} \hat{I}_{G}=0
$$

\footnotetext{
${ }^{14}$ We suppress argument $\bar{w}_{n e t}^{S}$ in $\hat{m}$.

${ }^{15}$ Recall that $\hat{I}$ is the level of immigration which is implicitly given by (16).
} 
where the implicit function theorem implies that

$$
\hat{I}_{G}(G)=\frac{\tilde{I}^{\prime}(W(G,-\hat{I})) W_{G}(G,-\hat{I})}{1+\left[\tilde{I}^{\prime}(\cdot) W_{m}\right]_{I=\hat{I}}} .
$$

Under stability, analogously to (19), the denominator of the right-hand side of (21) is positive. Thus, the first order condition (20) for a source economy becomes $W_{G}(G,-\hat{I}(G))=$ 0. Again, the second order condition holds.

It is interesting to note that, at the optimal public investment levels, emigration is minimized in a source economy of high-skilled expatriates and immigration is maximized in host economies. To see this formally, note that $\hat{m}_{G}=0$ if and only if $W_{G}=0$ for source economies. At the so-defined level of $G, \hat{m}_{G G}>0$, according to (19). Similarly, $\hat{I}_{G}=0$ if $W_{G}=0$ and $\hat{I}_{G G}<0$ at that level of $G$. These results are implied by the basic properties of the model. Recall that the government objective is to maximize net wage income of workers at home. Income opportunities abroad relative to those at home form the basis for migration decisions. Both skilled workers and the government take net wage rates abroad as given. The government problem and individual migration decisions are thus based on the same variable, the wage rate for skilled labor at home, $w_{n e t}^{S}$. The question now is in which way the migration of skilled labor affects public investment levels.

In equilibrium, the expectation whether to be host or source economy is self-fulfilling. Any fraction of host economies $\lambda$ is a potential equilibrium value. For concreteness, we focus on $\lambda=0.5$. According to (17), this implies $I=m$. Let us denote by $G_{1}^{*}$ and $G_{2}^{*}$ the equilibrium public investment level of a source economy and host economy, respectively. In international equilibrium, the number of migrants in or out of a jurisdiction, $m^{*} \geq 0$, and investment levels $\left(G_{1}^{*}, G_{2}^{*}\right)$ are simultaneously given by equation system

$$
\begin{aligned}
W_{G}\left(G_{1}^{*}, m^{*}\right) & =0 \\
W_{G}\left(G_{2}^{*},-m^{*}\right) & =0 \\
m^{*} & =\Phi\left(\frac{W\left(G_{2}^{*},-m^{*}\right)}{W\left(G_{1}^{*}, m^{*}\right)}-1\right) .
\end{aligned}
$$


Let us write public investment levels defined by $W_{G}(G, m)=0$ and $W_{G}(G,-m)=0$ as $\tilde{G}_{1}(m)$ and $\tilde{G}_{2}(m)$, respectively, and define

$$
M(m) \equiv \Phi\left(\frac{W\left(\tilde{G}_{1}(m),-m\right)}{W\left(\tilde{G}_{2}(m), m\right)}-1\right)[=R H S]
$$

As follows from the notion of stability of equilibrium emigration, we must have that $M^{\prime}\left(m^{*}\right)<1$ for $m^{*} \geq 0$. Note that $M(0)=M^{\prime}(0)=0$.

Property $M^{\prime}(0)<1$ ensures that there exists a symmetric international equilibrium, in which there is no migration $(m=0)$ and all jurisdictions choose public investment level $G_{0}$ as defined by $W_{G}\left(G_{0}, 0\right)=0$. Moreover, there may be an asymmetric equilibrium with $m^{*}>0$ (like $m_{1}$ in Figure 2), such that (22)-(24) and $M^{\prime}\left(m^{*}\right)<1$ holds. The key characteristic of this equilibrium is that $G_{1}^{*}<G_{2}^{*}$; that is, source economies have a lower public investment level than host economies. This important result follows from property $W_{G m}<0$ and the definition of $\tilde{G}_{1}(m)$ and $\tilde{G}_{2}(m)$, respectively; that is, $\tilde{G}_{1}^{\prime}(m)<0$ and

$\tilde{G}_{2}^{\prime}(m)>0$. Because the marginal impact of increasing the public investment level on the utility of non-migrants decreases with higher brain drain and increases when more skilled workers immigrate, the analysis suggests a negative relationship between net emigration of an economy and its public investment level.

\section{Empirical Support}

The theoretical analysis suggests three main hypotheses. First, emigration incentives depend on relative income to potential destination economies. The prediction that income differences trigger migration flows has been examined empirically elsewhere. Recently, both Beine, Doquier and Ozden (2008) and Grogger and Hanson (2008) provide convincing evidence for the critical role of wage differences between country pairs on emigration rates of tertiary educated workers. Second, our increasing returns framework suggests that there is a feedback mechanism working from higher emigration to lower wage rates and income levels. Based on an alternative theoretical framework, this prediction is supported by evidence provided in Grossmann and Stadelmann (2008). Third, and most 
important for the purpose of this study, we have highlighted the interaction between emigration of high-skilled labor and an economy's public investment level. We have shown that the marginal impact of an increase in public investments on income of domestic workers decreases with higher emigration. The novel hypothesis we explore in this section thus is that a higher net emigration rate of high-skilled workers in an economy causes lower public investment levels, all other things equal. We test this prediction by focussing on OECD countries, for four reasons. First, our model has abstracted from the possibility that higher emigration may lead to economic gains in source economies, as discussed in the introduction (e.g. Mountford, 1997, among others). Such effects seem empirically relevant in poor countries, but not in advanced economies. Second, we want to avoid large institutional differences of countries in our data set. Third, data from OECD countries typically are of better quality and more comparable across countries. Fourth, and maybe most important, according to our theoretical analysis net rather than gross emigration rates matter for the relation to public investment levels. As will become apparent, however, for data availability reasons net emigration rates can only be constructed when restricting attention to OECD countries.

Examining the correlation between public expenditure and emigration cannot identify the direction of causation between the two. We therefore construct an instrument for net migration rates of skilled workers and provide instrumental-variable (IV) estimations in addition to OLS. For this we use a measure of social networks of migrants and exogenous country characteristics, both potentially affecting mobility costs of individuals, to explain bilateral migration flows.

\subsection{Data and Estimation Strategy}

The first challenge is to find a measure for the net emigration rate of high-skilled individuals for OECD countries. Doquier and Marfouk (2006) have established a dataset of (gross) emigration stocks and rates by educational attainment for the years 1990 and 2000. The authors count as emigrants all foreign-born individuals aged at least 25 who live in an OECD country and class them by educational attainment and country of origin. 
Thus, only emigration into OECD countries is captured, approximately $90 \%$ of educated migrants in the world. ${ }^{16}$ Doquier, Marfouk and Lowell (2007) extend the initial dataset by Doquier and Marfouk (2006) and provide bilateral emigration stocks of high-skilled persons from country $i$ living in OECD country $j$, denoted by $M_{i j}$. Furthermore, let $\mathcal{S}_{\text {All }}$ denote the set of all 195 countries in the data set (each one is a potential source country) and denote by $\mathcal{S}_{O E C D}$ the set of OECD countries (only these are potential host countries).

We construct the net emigration stock of an OECD country $j$ by aggregating its total emigration stock, $\sum_{i \in \mathcal{S}_{O E C D}} M_{j i}$, and deducting its total immigration stock, $\sum_{i \in \mathcal{S}_{\text {All }}} M_{i j}$. The net emigration stock of OECD country $j$ is denoted by

$$
\text { NetEmig }:=\sum_{i \in \mathcal{S}_{O E C D}} M_{j i}-\sum_{i \in \mathcal{S}_{A l l}} M_{i j}
$$

To adjust the emigration variable for the size of the skilled labor force, we divide the high-skilled net emigration stock by the stock of skilled residents in country $j, N_{j}$, and thereby obtain a net emigration rate: $M i g_{j}:=N e t E m i g_{j} / N_{j}$.

Denoting by $G_{j}$ the public investment level per capita of country $j$ we estimate the following equation for the year 2000:

$$
\log G_{j}=\alpha_{0}+\alpha_{1} M i g_{j}+\mathbf{x}_{j}^{\prime} \boldsymbol{\alpha}_{\mathbf{x}}+\varepsilon_{i}
$$

As the theoretical model predicts a negative impact of higher emigration on public investment, we expect $\alpha_{1}<0$. $\mathbf{x}_{j}$ is a vector of other controls potentially affecting public investment in country $j$. We include $(\log )$ population size in order to control for economies of scale associated with public goods. That is, if anything, population size should be negatively related to public expenditure per capita. Moreover, to account for the age structure of a country, which may affect public investments, we include the fraction of population under the age of 16. Finally, to deal with spending determinants which are not based on the optimality criterion employed in the theoretical model, we also

\footnotetext{
${ }^{16}$ See Doquier and Marfouk (2006) for a detailed discussion concerning data collection and construction issues.
} 
control for social spending per capita. Thereby we want, on the one hand, account for the possibility that governments' spending levels on both investment and non-investment expenditure categories are higher in some countries than in others for ideological reasons. This would suggest a positive relationship between the government investment and social spending. On the other hand, governments may substitute public investments for welfare expenses. This would imply a negative relationship between the two spending categories. $\varepsilon_{j}$ is an error term.

We use four different OECD measures of public expenditure as dependent variable: government gross fixed capital formation, total publicly financed R\&D spending, R\&D spending on higher education, and total public education expenditure (all in logs). The first category may be most suited in light of the theoretical model, as it represents public infrastructure spending. We analyze the effects on this category first and discuss the other measures in somewhat less detail.

To mitigate potential omitted variable bias, we also take first differences of equation (27) and regress the (approximate) growth rate of public investment per capita in country $j$ on the change in the emigration rate of skilled migrants between 1990 and 2000:

$$
\log \left(G_{j, t} / G_{j, t-1}\right)=\beta_{0}+\beta_{1} \text { DeltaMig } g_{j}+\mathbf{z}_{j}^{\prime} \boldsymbol{\beta}_{z}+\eta_{j}
$$

where time indices $t$ and $t-1$ refer to years 2000 and 1990, respectively, and DeltaMig $:=$ $M i g_{j, t}-M i g_{j, t-1}$. According to the theoretical model, we expect $\beta_{1}<0$. $\mathbf{z}_{j}$ is a vector of other controls potentially affecting the rate of change of public investment over time. We include the difference of $\log$ population size between 1990 and 2000 and the growth rate of GDP per capita in that time period as controls. The latter accounts for adjustment in spending due to business cycle phenomena. $\eta_{j}$ is an error term. The data sources and summary statistics of the employed variables are presented in Table 1.

\section{$<$ Table $1>$}

To deal with potential endogeneity bias regarding the relationships of interest, we construct an instrument for the net emigration rate of the year $2000\left(M i g_{j, t}\right)$ as well 
as its change between 1990 and $2000\left(\right.$ DeltaMig $\left._{j}\right)$ to estimate equations (27) and (28), respectively. To obtain our instrument for net emigration rates of skilled labor, we exploit the availability of bilateral migration stocks. The procedure is similar to the instrumentation strategy to construct aggregate trade flows of a country in the widelycited contribution of Frankel and Romer (1999) on the impact of higher trade flows on income per capita. Instead of predicting total trade flows we predict total net emigration rates of countries.

We first estimate the $(\log )$ stock of skilled expatriates from $i$ living in OECD country $j$ in year 2000, $\log M_{i j, t}$, as function of variables which are supposed to capture migration costs: the total stock of emigration (sum over all education categories) in the year 1990 (in logs) migrating from country $i$ to $j$, TotalMig $g_{i j, t-1}$, countries' log geodesic distances, Dist $_{i j}$, a dummy indicating whether at least 9 percent of the population in $i$ and $j$ speak a common language, ComLang $i j$, and a dummy indicating whether $i$ and $j$ were both transition economies in 1990, Transition $_{i j}$. The inclusion of TotalMigij,t-1 is motivated by the notion that a larger community of people from the same nation already living abroad create mobility-cost reducing network effects, as argued by Beine, Doquier and Ozden (2008), among others. Our indicators for geographic and linguistic proximity are also typically used in the brain drain literature. The dummy on transition countries is potentially important as well, since the time period we consider was shortly after the fall of the iron curtain. This event has newly created the possibility to emigrate from a former communist country to non-transition countries, whereas migration between communist countries was already possible before 1990. The following equation presents the estimated value of bilateral migration stocks with 3515 bilateral observations (standard errors in parenthesis):

$$
\begin{aligned}
\log \hat{M}_{i j, t}= & \underset{(0.375)}{-1.407}+\underset{(0.006)}{0.866} \times \text { TotalMig }_{i j, t-1}-\underset{(0.021)}{0.218} \times \text { Dist }_{i j}+ \\
& \underset{(0.044)}{0.813} \times \text { ComLang }_{i j}-\underset{(0.092)}{0.836} \times \text { Transition }_{i j} .
\end{aligned}
$$

All coefficients have the expected sign and are significantly different from zero at the 
one percent level. Moreover, the left-hand side variables explain about 92 percent of the variation of bilateral migration stocks $\left(R^{2}=0.917\right)$.

We then recover $\hat{M}_{i j}$ from (29) to construct a predicted net migration rate for the year 2000, $\widehat{M i g}_{j}$, analogously to the use of $M_{i j}$ to construct $M i g_{j}$. The correlation coefficient of the true overall net emigration rate $\mathrm{Mig}_{j}$ with the constructed net emigration rate, $\widehat{M i g}_{j}$ is 86 percent (see Figure A1 for a scatterplot).

In our instrumental-variable estimations we use $\widehat{\operatorname{Mig}}_{j}$ and $\widehat{D e l t a M}_{i} g_{j}:=\widehat{M i g}_{j, t}-$ $\mathrm{Mig}_{j, t-1}$ instead of their actual values for estimating (27) and (28), respectively. The key identifying assumption for a causal effect of emigration on public investment is that the instruments are uncorrelated with residuals in equations (27) and (28).

\subsection{Results}

Table 2 presents OLS estimates of level-regressions (27) in specifications (1) to (4) and change-regressions (28) in specifications (5) to (8) using both OLS and IV. We use the official OECD measure for government investment (government gross fixed capital formation) in logs, PubInv, for all regressions in Table 2.

\section{$<$ Table $2>$}

In specifications (1) to (4) the coefficient of interest, $\alpha_{1}$, is always negative. In column (1), we look at the effect of the net emigration rate ( $\mathrm{Mig}$ ) on public investment in 22 OECD countries using OLS without any controls. Column (2) uses instead the constructed net emigration rate $(\widehat{M i g})$ as an instrument for the actual net emigration rate. The results provide no evidence that ordinary least-squares estimates overstate the negative effect on public investment. The two coefficients in column (1) and column (2) roughly have the same size. The instrument itself proves to be highly significant when considering the first stage F-Test. Columns (3) and (4) represent OLS and IV regressions, respectively, when controlling for log population size (Pop), fraction of population under sixteen (Pop16) and (log) social expenditure per capita (SocialExp) in addition to the net migration rate. The influence of emigration on public investment remains negative when the controls are added and statistical significance increases. Quantitatively, the 
estimates suggest that effects of brain drain on public investment are non-negligible. With $\alpha_{1}$ being approximately equal to -2 , an increase in the net emigration rate of one standard deviation (equal to 0.11, according to Table 1) leads to a reduction in public investment expenditure per capita of about 22 percent.

Turning to the estimates of change-regressions (28) confirms the results of the levelregressions. An increase in the difference of the net emigration rate between 1990 and 2000 has a negative effect on the growth rate of the public investment level per capita, where $\beta_{1}$ is significantly different from zero at least at the 10 percent level, according to columns (5) to (10) in Table 2. Again, OLS- and IV-estimates are in the same range. As expected, also the growth rate of GDP per capita (DeltaGDP) has a positive effect. Controlling for it as well as for the growth rate of population size (DeltaPop) reduces $\beta_{1}$ considerably. Still, the evidence from this estimate suggests that an increase in the change in the net migration rate over time (DeltaMig) by one standard deviation reduces the growth rate of public investment per capita by about $(0.05 \times 1.1=) 5.5$ percentage points. Like for the level-regressions, also for the change-regressions which give IV-estimates, in columns (6), (8) and (10) of Table 2, the F-Test shows that the first stage is always significant with the proposed instrument.

\section{$<$ Table $3>$}

In Table 3 we provide OLS and IV results of level-regressions (27) for other public expenditure categories than government gross fixed capital formation. These measure are for specifications (1) to (3) total government R\&D expenditure per capita (R\&DTotal), for specifications (4) to (6) R\&D expenditure in higher education per capita (R\&DHigherEdu), and finally for specifications (7) to (9) public education expenditure per capita $(\operatorname{ExpEdu})$. The coefficient of interest, $\alpha_{1}$, is negative and statistically significant at least at the 10 percent level for the IV-estimates. Coefficients are smaller for IV-estimates than for OLS-estimates. But the magnitude of $\alpha_{1}$ is comparable to the estimates in Table 2 , when the full set of controls is included. ${ }^{17}$

\footnotetext{
${ }^{17}$ We experimented with other public expenditure categories such as social spending, the OECD measure for expenditure for economic affairs, public expenditures for housing, and total government
} 


\section{$<$ Table $4>$}

Table 4 presents OLS and IV estimations of equation (28) when growth rates of the same expenditure measures than in Table 3 are used as dependent variables. For both $\mathrm{R} \& \mathrm{D}$ measures, $\beta_{1}$ is again negative. The IV-estimates of $\beta_{1}$ are highly significant and quantitatively much larger (by a factor of about four) than in the case where the growth rate of government gross fixed capital formation is the dependent variable (Table 2). For public education expenditure, IV-estimates of $\beta_{1}$ are not significant but again negative and about the same size than the OLS-estimate (which is significant).

\section{$<$ Table $5>$}

In Table 5 we examine whether the negative impact of higher net emigration on public investment still holds when we employ spending as fraction of GDP rather than per capita spending as dependent variable. This variable, however, is different to variable $G$ in the theoretical model. A negative impact of a higher emigration rate on the fraction of public investment in GDP is less likely to hold than on public investment per capita, since both $G$ and income change in the same direction as response to migration flows, according to the proposed theory. Nevertheless, a negative effect of higher (instrumented) net emigration on spending shares holds and is statistically significant at least at the 10 percent level in the preferred first difference estimates, except for education expenditure.

\section{$<$ Table $6>$}

So far we looked at the role of higher net emigration for public investments. However, it may be the case that skilled immigrants are not perfectly substitutable to skilled emigrants and that our previous empirical results are driven by immigrants or emigrants only. In Table 6 we report estimates which allow for a differential impact of higher immigration to higher emigration. It reveals that higher emigration has negative effects and higher immigration typically has positive effects on public spending per capita, as

expenditures. These measures do not reflect measures of public investment in spirit of our theory, as they include government consumption or transfers. For these measures, effects of an increase in the net emigration rate of high-skilled labor are either insignificant (for housing and total expenditure) or positive (for social expenditures and spending on economic affairs). 
expected, although coefficients are not always significant. We also see that the magnitudes of the effects of higher immigration are not always similar to those of higher emigration. Nevertheless, it is not the case that the impact of a marginal increase in the immigration rate is systematically higher or systematically lower than that of an increase in the emigration rate.

\section{Conclusion}

In this paper, we analyzed theoretically and empirically the relationship between migration of high-skilled individuals, income differences, and differences in public investment levels across jurisdictions. According to the theoretical model, migration of skilled labor may endogenously arise despite symmetry of jurisdictions ex ante. This possibility arises

from the assumption of human capital externalities, which imply that outflows of skilled labor reduce wage rates in source economies whereas inflows raise them in destination economies. Most importantly, the analysis suggests that higher outward migration reduces the impact of an increase in productivity-enhancing public expenditure on both gross and net income levels of workers, whereas higher inward migration increases it. Consequently, governments who care about welfare of the domestic labor force adjust public investment levels downward when facing brain drain and upward when experiencing inflows of skilled labor.

We presented empirical evidence which is consistent with this main prediction of the theory. The main innovation in the empirical part was to construct and employ an instrument for the net emigration rate of a country in order to establish a causal effect. We showed that an increase in the predicted net emigration rate causes quite substantial reductions of various measures of public investment levels per capita among OECD countries. Consequently, our analysis suggests that more pronounced international migration patterns for skilled labor are likely to aggravate differences in public investment levels across countries, along with income differences. 


\section{References}

[1] Andersson, Fredrik and Kai A. Konrad (2003). Human capital investment and globalization in extortionary states, Journal of Public Economics 87, 1539-1555.

[2] Auriol, Laudeline (2007). Labour market characteristics and international mobility of doctorate holders: Results for seven countries, OECD STI Working Paper 2007/2.

[3] Bhagwati, Jagdish N. and Koichi Hamada (1974). The brain drain, international integration of markets for professionals and unemployment, Journal of Development Economics 1, 19-42.

[4] Bhagwati, Jagdish N. and John D. Wilson, eds. (1989). Income taxation and international mobility, Cambridge, MA: MIT Press.

[5] Beine, Michel, Frédéric Doquier and Caglar Ozden (2008). Diasporas, University of Luxembourg, mimeo.

[6] Beine, Michel, Frédéric Docquier and Hillel Rapoport (2001). Brain drain and economic growth: theory and evidence, Journal of Development Economics 64, 275-89.

[7] Beine, Michel, Fréderic Doquier and Hillel Rapoport (2008). Brain drain and human capital formation in developing countries: winners and losers, Economic Journal 118, 631-652.

[8] Bucovetsky, Sam (2003). Efficient migration and redistribution, Journal of Public Economics 87, 2459-2474.

[9] Card, David (2009). Immigration and inequality, American Economic Review 99, 1-21.

[10] Congressional Budget Office (2005). The role of immigrants in the U.S. labor market, November.

[11] Council of Europe (1995). Recommendation No. R (95) 7 of the Committee of Ministers to member states on brain drain in the sectors of higher education and research. 
[12] Doquier, Frédéric, B. Lindsay Lowell and Abdeslam Marfouk (2007). A Gendered Assessment of the Brain Drain, IZA Discussion Papers No. 3235.

[13] Doquier, Frédéric and Aldeslam Marfouk (2006). International migration by educational attainment (1990-2000) - Release 1.1, in: C. Ozden and M. Schiff (eds), International Migration, Remittances and Development, Palgrave Macmillan, New York.

[14] Egger, Hartmut, Josef Falkinger and Volker Grossmann (2009). Brain drain, fiscal competition, and public education expenditure, IZA Discussion Paper No. 2747.

[15] Egger, Hartmut, Peter Egger, Josef Falkinger and Volker Grossmann (2009). The impact of capital market integration on educational choice and the consequences for economic growth, University of Zurich, mimeo.

[16] European Commission (2003). Third European Report on Science \& Technology Indicators 2003: Towards a Knowledge-based Economy, http://cordis.europa.eu/indicators/third_report.htm.

[17] European Commission (2007). Proposal for a Council Directive on the conditions of entry and residence of third-country nationals for the purpose of highly qualified employment, $\operatorname{COM}(2007) 637$.

[18] Frankel, Jeffrey A. and David Romer (1999). Does Trade Cause Growth? American Economic Review 89, 379-399.

[19] Grogger, Jeffrey and Gordon H. Hanson (2008). Income maximization and the selection and sorting of international migrants, NBER Working Paper No. 13821.

[20] Grossmann, Volker and David Stadelmann (2008). International mobility of the highly skilled, endogenous R\&D, and public infrastrucutre investment, IZA Discussion Paper No. 3366.

[21] Johnson, George E. (1997). Changes in earnings inequality: the role of demand shifts, Journal of Economic Perspectives 11, 41-54. 
[22] Justman, Moshe and Jacques-François Thisse (1997). Implications of the Mobility of Skilled Labor for Local Public Funding of Higher Education, Economics Letters $55,409-412$.

[23] Justman, Moshe and Jacques-François Thisse (2000). Local Public Funding of Higher Education when Skilled Labor is Mobile, International Tax and Public Finance 7, 247-258.

[24] Lucas, Robert E. (1988). On the mechanics of economic development, Journal of Monetary Economics 22, 3-42.

[25] Miyagiwa, Kaz (1991). Scale economies in education and the brain drain problem, International Economic Review 32, 743-759.

[26] Mountford, Andrew (1997). Can a brain drain be good for growth in the source economy?, Journal of Development Economics 53, 287-303.

[27] OECD (2008). OECD Economic Outlook, Volume 2008/1, No. 83, June,OECD, Paris.

[28] Poutvaara, Panu (2004). Educating Europe: Should public education be financed with graduate taxes or income-contingent loans?, CESifo Economic Studies 50, 663684.

[29] Poutvaara, Panu (2008). Public education in an integrated Europe: Studying to migrate and teaching to stay?, Scandinavian Journal of Economics 110, 591-608.

[30] Saint-Paul, Gilles (2004). The brain drain: Some evidence from European expatriates in the United States, IZA Discussion Paper No. 1310.

[31] Stark, Oded, Christian Helmenstein and Alexia Prskawetz (1997). A brain gain with a brain drain, Economics Letters 55 (2), 227-234.

[32] Stark, Oded, Christian Helmenstein and Alexia Prskawetz (1998). Human capital depletion, human capital formation, and migration: a blessing in a 'curse'?, Economics Letters 60, 363-367. 
[33] Wildasin David (2000). Labor-market integration, investment in risky human capital, and fiscal competition, American Economic Review 90, 73-95.

[34] Wilson, John D. (2008). A voluntary brain-drain tax, Journal of Public Economics 92, 2385-2391. 
Net emigration rates and government investment in OECD countries
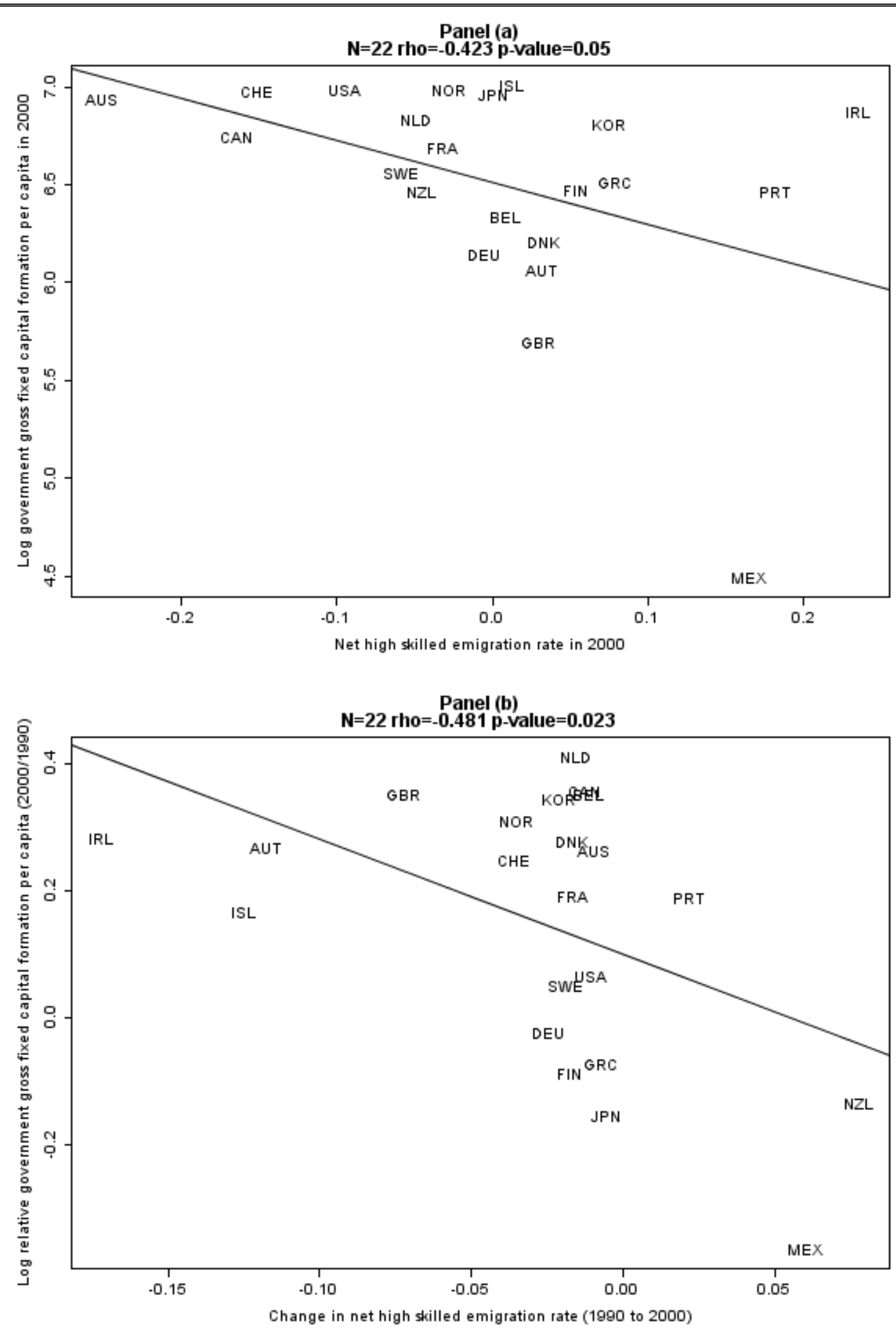

Notes: rho represents the correlation coefficient. The p-value results from a test of the significance of the correlation. For the construction of the net emigration rate see description in subsection 4.1. Government gross fixed capital formation is taken for the years 1990 and 2000 from OECD (2008). 
Figure 2

Migration in equilibrium for given public investment

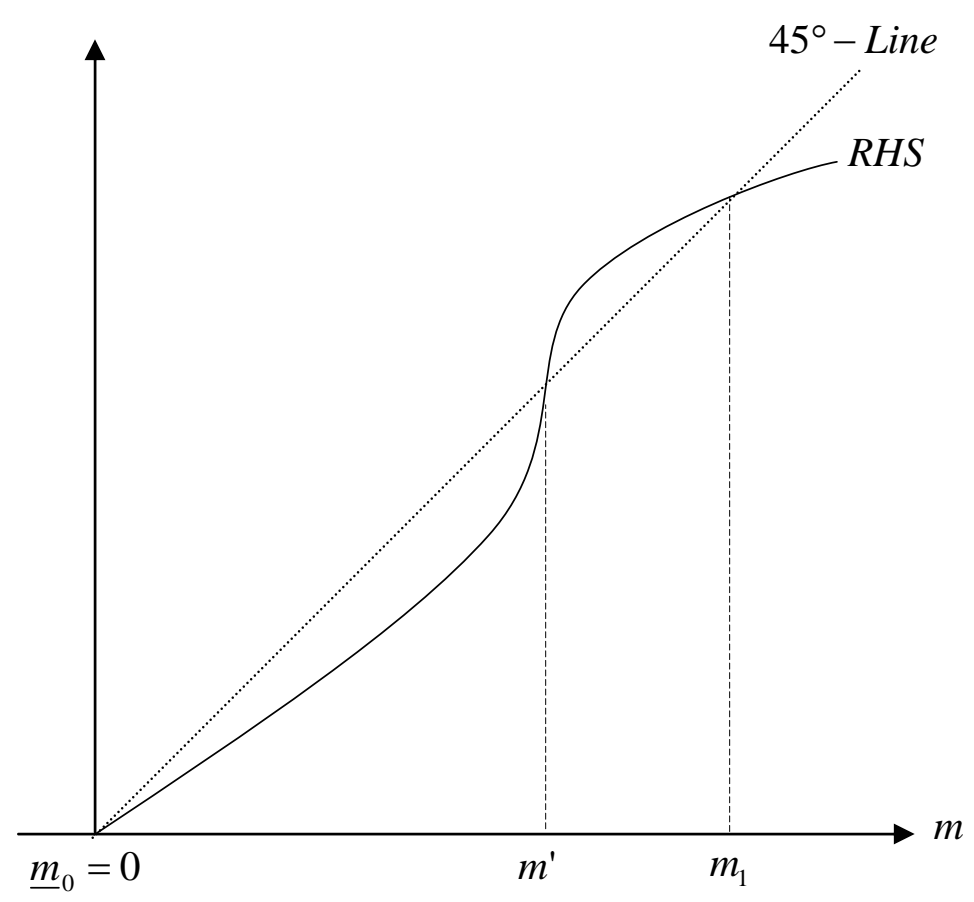


Figure A1

Actual versus constructed net emigration rate

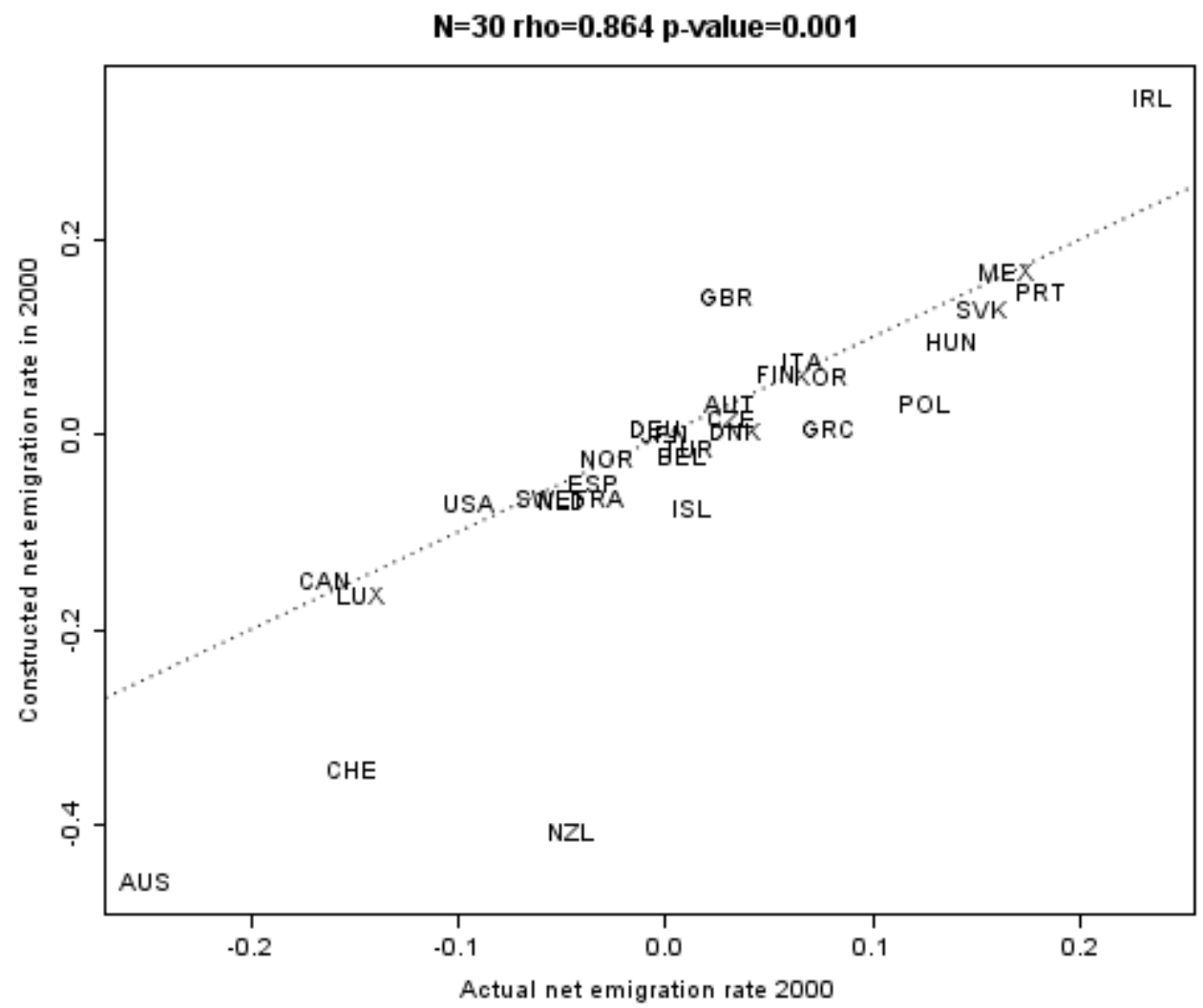

Notes: rho represents the correlation coefficient. The p-value results from a test of the significance of the correlation. The dotted line represents the 45-degree line. 
Table 1

Data description and sources

\begin{tabular}{|c|c|c|c|c|}
\hline Variable & Description and source & $N$ & Mean & S.D. \\
\hline Mig & $\begin{array}{l}\text { Net emigration rate in year 2000. See description in } \\
\text { section } 4.1 \text { for construction, with data from Docquier, } \\
\text { Marfouk and Lowell (2007). }\end{array}$ & 30 & 0.01243 & 0.10923 \\
\hline DeltaMig & Mig of year 2000 minus Mig of year 1990 & 30 & -0.02455 & 0.04885 \\
\hline PubInv & $\begin{array}{l}\text { Log of government gross fixed capital formation per } \\
\text { capita in year } 2000 \text {. OECD (2008). }\end{array}$ & 22 & 6.506 & 0.57332 \\
\hline DeltaPubInv & PubInv in 2000 minus PubInv in 1990. & 22 & 0.1478 & 0.20903 \\
\hline R\&DTotal & $\begin{array}{l}\text { Log of total government R\&D expenditure per capita } \\
\text { in year } 2000 \text {. OECD Education Statistics Database. }\end{array}$ & 30 & 5.807 & 1.00128 \\
\hline DeltaR\&DTotal & R\&DTotal in 2000 minus by R\&DTotal in 1990. & 25 & 0.6278 & 0.34107 \\
\hline R\&DHigherEdu & $\begin{array}{l}\text { Log of (publicly financed) R\&D expenditure in higher } \\
\text { education per capita in year 2000. OECD Education } \\
\text { Statistics Database. }\end{array}$ & 30 & 4.175 & 1.03412 \\
\hline DeltaR\&DHigherEdu & $\begin{array}{l}\text { ReDHigherEdu in } 2000 \text { minus R\&DHigherEdu in } \\
1990 .\end{array}$ & 22 & 0.6389 & 0.3128 \\
\hline$E x p E d u$ & $\begin{array}{l}\text { Log of expenditure per capita for education in } 2000 . \\
\text { OECD General Government Accounts Database. }\end{array}$ & 25 & 7.201 & 0.40681 \\
\hline DeltaExpEdu & ExpEdu in 2000 minus by ExpEdu in 1990 & 22 & 0.3254 & 0.32131 \\
\hline Pop & $\begin{array}{l}\text { Log Population mid-year estimate in year 2000. OECD } \\
\text { Population and Labor Force Statistics Database. }\end{array}$ & 30 & 9.617 & 1.55114 \\
\hline DeltaPop & Pop in 2000 divided by Pop in 1990. & 30 & 1.075 & 0.06834 \\
\hline Pop16 & $\begin{array}{l}\text { Population under } 16 \text { as share of whole population in } \\
\text { year 2000. OECD Population and Labor Force } \\
\text { Statistics Database. }\end{array}$ & 30 & 19.28 & 4.23753 \\
\hline SocialExp & $\begin{array}{l}\text { Log of social expenditure per capita in year } 2000 . \\
\text { Government Regulation Size. OECD General } \\
\text { Government Accounts Database. }\end{array}$ & 30 & 8.007 & 0.66004 \\
\hline DeltaGDP & $\begin{array}{l}\text { Log real GDP in } 2000 \text { minus log real GDP in } 1990 . \\
\text { Penn World Tables 6.2. }\end{array}$ & 30 & 1.243 & 0.17745 \\
\hline$M_{i j}$ & $\begin{array}{l}\text { Stock of emigrants of educational category "high" aged } \\
25+\text { born in country } i \text { and living in OECD country } j \text { in } \\
\text { year } 2000 . \text { Docquier, Marfouk and Lowell (2007). }\end{array}$ & 3560 & 5.296 & 2.70399 \\
\hline TotalMig $_{i j}$ & $\begin{array}{l}\text { Log size of total emigrant population from country } i \\
\text { living in country } j \text { in year 1990. Docquier, Marfouk and } \\
\text { Lowell (2007). }\end{array}$ & 3560 & 5.761 & 2.83947 \\
\hline Dist $_{i j}$ & $\begin{array}{l}\text { Log geodesic distance in } \mathrm{kms} \text { between country } i \text { and } j \text {. } \\
\text { Mayer and Soledad (2006). }\end{array}$ & 3515 & 8.476 & 0.92755 \\
\hline ComLang $_{i j}$ & $\begin{array}{l}\text { Identifier if same language is spoken by at least } 9 \% \text { of } \\
\text { the population in country } i \text { and } j \text {. Mayer and Soledad } \\
(2006) \text {. }\end{array}$ & 3525 & 0.1231 & 0.32862 \\
\hline Transition $_{i j}$ & $\begin{array}{l}\text { Dummy variable capturing if country } i \text { and } j \text { were } \\
\text { economic transition countries. }\end{array}$ & 3560 & 0.01938 & 0.13788 \\
\hline
\end{tabular}

Note: The range, mean and standard deviations are based on the respective number of observations. 
Table 2

Effect of high-skilled net emigration rates on government gross fixed capital formation per capita: level and first difference estimates

\begin{tabular}{|c|c|c|c|c|c|c|c|c|c|c|}
\hline & $\begin{array}{l}\text { OLS } \\
\text { (1) }\end{array}$ & $\begin{array}{l}I V \\
(2)\end{array}$ & $\begin{array}{c}\text { OLS } \\
\text { (3) }\end{array}$ & $\begin{array}{l}I V \\
(4)\end{array}$ & $\begin{array}{l}\text { OLS } \\
\text { (5) }\end{array}$ & $\begin{array}{l}I V \\
(6)\end{array}$ & $\begin{array}{c}O L S \\
(7)\end{array}$ & $\begin{array}{l}I V \\
(8)\end{array}$ & $\begin{array}{l}\text { OLS } \\
\text { (9) }\end{array}$ & $\begin{array}{l}I V \\
(10)\end{array}$ \\
\hline Dependent V ariable & \multicolumn{4}{|c|}{ PubInv } & \multicolumn{6}{|c|}{ DeltaPubInv } \\
\hline (Intercept) & $\begin{array}{c}6.5090^{* * *} \\
(0.1068)\end{array}$ & $\begin{array}{c}6.5090^{* * *} \\
(0.1096)\end{array}$ & $\begin{array}{c}11.9469^{* * *} \\
(1.5138)\end{array}$ & $\begin{array}{c}11.7402^{* * *} \\
(1.6411)\end{array}$ & $\begin{array}{c}0.0995^{* * *} \\
(0.0473)\end{array}$ & $\begin{array}{l}0.0928^{* *} \\
(0.0517)\end{array}$ & $\begin{array}{l}1.1545^{* * *} \\
(0.5054)\end{array}$ & $\begin{array}{l}1.0883^{* *} \\
(0.5517)\end{array}$ & $\begin{array}{c}0.8836 \\
(0.6198)\end{array}$ & $\begin{array}{c}0.5947 \\
(0.5834)\end{array}$ \\
\hline Mig & $\begin{array}{l}-2.1590^{*} \\
(1.3304)\end{array}$ & $\begin{array}{l}-2.1860^{*} \\
(1.3910)\end{array}$ & $\begin{array}{c}-2.3280^{* * *} \\
(0.8947)\end{array}$ & $\begin{array}{c}-1.9221^{* *} \\
(1.0186)\end{array}$ & & & & & & \\
\hline DeltaMig & & & & & $\begin{array}{c}-1.8176^{* * *} \\
(0.6688)\end{array}$ & $\begin{array}{c}-2.0689^{* *} \\
(1.1792)\end{array}$ & $\begin{array}{c}-1.6010^{* * *} \\
(0.5312)\end{array}$ & $\begin{array}{c}-1.2474^{* *} \\
(0.7370)\end{array}$ & $\begin{array}{c}-1.1536^{* * *} \\
(0.5471)\end{array}$ & $\begin{array}{c}-1.1224^{* *} \\
(0.5933)\end{array}$ \\
\hline Pop & & & $\begin{array}{c}-0.1430^{* * *} \\
(0.0626)\end{array}$ & $\begin{array}{c}-0.1376^{* *} \\
(0.0713)\end{array}$ & & & & & & \\
\hline Pop16 & & & $\begin{array}{c}-0.0853^{* * *} \\
(0.0275)\end{array}$ & $\begin{array}{c}-0.0857^{* * *} \\
(0.0323)\end{array}$ & & & & & & \\
\hline SocialExp & & & $\begin{array}{c}-0.2984^{* * *} \\
(0.1094)\end{array}$ & $\begin{array}{c}-0.2782^{* * *} \\
(0.1159)\end{array}$ & & & & & & \\
\hline DeltaPop & & & & & & & $\begin{array}{c}-0.9673^{* * *} \\
(0.4569)\end{array}$ & $\begin{array}{c}-0.9064^{* *} \\
(0.4975)\end{array}$ & $\begin{array}{c}-1.0452^{* * *} \\
(0.4588)\end{array}$ & $\begin{array}{c}-0.9427^{* *} \\
(0.4700)\end{array}$ \\
\hline DeltaGDP & & & & & & & & & $\begin{array}{c}0.2929 \\
(0.2084)\end{array}$ & $\begin{array}{c}0.4283^{* * *} \\
(0.1807)\end{array}$ \\
\hline F-value (First Stage) & & 59.720 & & 22.500 & & 31.690 & & 15.120 & & 20.080 \\
\hline Adj. R2 & 0.138 & 0.094 & 0.430 & 0.331 & 0.193 & 0.143 & 0.243 & 0.175 & 0.255 & 0.279 \\
\hline No. of obs. & 22 & 22 & 22 & 22 & 22 & 22 & 22 & 22 & 22 & 22 \\
\hline
\end{tabular}

Notes: Robust clustered standard errors in parenthesis. ${ }^{* * *}$ indicates a significance level below 5 percent; ${ }^{* *}$ indicates significance level between 5 and 10 percent; ${ }^{*}$ indicates significance level between 10 and 15 percent. 
Table 3

Effect of high-skilled net emigration rates on alternative measures of public investment per capita: level estimates

\begin{tabular}{|c|c|c|c|c|c|c|c|c|c|}
\hline & $\begin{array}{l}O L S \\
(1)\end{array}$ & $\begin{array}{l}I V \\
(2)\end{array}$ & $\begin{array}{l}I V \\
(3)\end{array}$ & $\begin{array}{l}O L S \\
\text { (4) }\end{array}$ & $\begin{array}{l}I V \\
(5)\end{array}$ & $\begin{array}{l}I V \\
(6)\end{array}$ & $\begin{array}{l}\text { OLS } \\
(7)\end{array}$ & $\begin{array}{c}I V \\
(8)\end{array}$ & $\begin{array}{l}I V \\
(9)\end{array}$ \\
\hline Dependent V ariable & \multicolumn{3}{|c|}{ R\&DTotal } & \multicolumn{3}{|c|}{ RevHigherEdu } & \multicolumn{3}{|c|}{$E x p E d u$} \\
\hline (Intercept) & $\begin{array}{l}5.8720^{* * *} \\
(0.1453)\end{array}$ & $\begin{array}{l}5.8510^{* * *} \\
(0.1662)\end{array}$ & $\begin{array}{c}4.3558 \\
(3.8846)\end{array}$ & $\begin{array}{c}4.2160^{* * *} \\
(0.1819)\end{array}$ & $\begin{array}{c}4.2100^{* * *} \\
(0.1810)\end{array}$ & $\begin{array}{c}2.0159 \\
(2.8938)\end{array}$ & $\begin{array}{l}7.2320^{* * *} \\
(0.0627)\end{array}$ & $\begin{array}{l}7.2250^{* * *} \\
(0.0715)\end{array}$ & $\begin{array}{c}3.3130^{* * *} \\
(0.9476)\end{array}$ \\
\hline Mig & $\begin{array}{c}-5.2180^{* * *} \\
(1.4798)\end{array}$ & $\begin{array}{c}-3.5750^{* * *} \\
(1.6768)\end{array}$ & $\begin{array}{c}-2.6568^{* *} \\
(1.3257)\end{array}$ & $\begin{array}{l}-3.3570^{*} \\
(1.9897)\end{array}$ & $\begin{array}{c}-2.8640^{* *} \\
(1.6406)\end{array}$ & $\begin{array}{c}-2.6240^{* *} \\
(1.4049)\end{array}$ & $\begin{array}{c}-2.2510^{* * *} \\
(0.7819)\end{array}$ & $\begin{array}{c}-1.7150^{* *} \\
(0.9547)\end{array}$ & $\begin{array}{c}-1.5746^{* * *} \\
(0.5154)\end{array}$ \\
\hline Pop & & & $\begin{array}{l}-0.0962 \\
(0.1100)\end{array}$ & & & $\begin{array}{c}0.0931 \\
(0.1832)\end{array}$ & & & $\begin{array}{l}-0.0178 \\
(0.0232)\end{array}$ \\
\hline Pop16 & & & $\begin{array}{l}-0.0529 \\
(0.0408)\end{array}$ & & & $\begin{array}{l}-0.0475 \\
(0.0325)\end{array}$ & & & $\begin{array}{c}0.1019^{* * *} \\
(0.0201)\end{array}$ \\
\hline SocialExp & & & $\begin{array}{c}0.4283 \\
(0.3571)\end{array}$ & & & $\begin{array}{c}0.2763 \\
(0.2937)\end{array}$ & & & $\begin{array}{c}0.2769^{* * *} \\
(0.0729)\end{array}$ \\
\hline F-value (First Stage) & & 82.150 & 28.080 & & 82.150 & 28.080 & & 85.860 & 35.500 \\
\hline Adj. R2 & 0.300 & 0.082 & 0.287 & 0.097 & 0.095 & 0.089 & 0.263 & 0.197 & 0.647 \\
\hline No. of obs. & 30 & 30 & 30 & 30 & 30 & 30 & 25 & 25 & 25 \\
\hline
\end{tabular}

Notes: Robust clustered standard errors in parenthesis. ${ }^{* * *}$ indicates a significance level below 5 percent; ${ }^{* *}$ indicates significance level between 5 and 10 percent; ${ }^{*}$ indicates significance level between 10 and 15 percent. 
Table 4

Effect of high-skilled net emigration rates on alternative measures of public investment per capita: first difference estimates

\begin{tabular}{|c|c|c|c|c|c|c|c|c|c|}
\hline & $\begin{array}{l}O L S \\
\text { (1) }\end{array}$ & $\begin{array}{l}I V \\
(2)\end{array}$ & $\begin{array}{l}I V \\
(3)\end{array}$ & $\begin{array}{l}O L S \\
\text { (4) }\end{array}$ & $\begin{array}{l}I V \\
(5)\end{array}$ & $\begin{array}{l}I V \\
(6)\end{array}$ & $\begin{array}{l}\text { OLS } \\
(7)\end{array}$ & $\begin{array}{l}I V \\
(8)\end{array}$ & $\begin{array}{l}I V \\
(9)\end{array}$ \\
\hline Dependent Variable & \multicolumn{3}{|c|}{ DeltaR\&DTotal } & \multicolumn{3}{|c|}{ DeltaR\&DHigherEdu } & \multicolumn{3}{|c|}{ DeltaExpEdu } \\
\hline (Intercept) & $\begin{array}{c}0.5486^{* * *} \\
(0.0633)\end{array}$ & $\begin{array}{c}0.4980^{* * *} \\
(0.0746)\end{array}$ & $\begin{array}{c}0.0798 \\
(1.3760)\end{array}$ & $\begin{array}{c}0.5883^{* * *} \\
(0.0714)\end{array}$ & $\begin{array}{c}0.5272^{* * *} \\
(0.0760)\end{array}$ & $\begin{array}{c}0.6478 \\
(1.1044)\end{array}$ & $\begin{array}{c}0.2098^{* * *} \\
(0.0915)\end{array}$ & $\begin{array}{l}0.2062^{* *} \\
(0.1149)\end{array}$ & $\begin{array}{l}-0.6920 \\
(0.6389)\end{array}$ \\
\hline DeltaMig & $\begin{array}{c}-2.8325^{* * *} \\
(1.2773)\end{array}$ & $\begin{array}{c}-4.6440^{* * *} \\
(1.8638)\end{array}$ & $\begin{array}{c}-4.7351^{* * *} \\
(1.9600)\end{array}$ & $\begin{array}{l}-1.8954^{*} \\
(1.1400)\end{array}$ & $\begin{array}{c}-4.1850^{* * *} \\
(1.3879)\end{array}$ & $\begin{array}{c}-4.2283^{* * *} \\
(1.6199)\end{array}$ & $\begin{array}{c}-3.5534^{* *} \\
(1.7572)\end{array}$ & $\begin{array}{l}-3.6640 \\
(3.0073)\end{array}$ & $\begin{array}{l}-3.0804 \\
(3.1596)\end{array}$ \\
\hline DeltaPop & & & $\begin{array}{c}0.3600 \\
(1.3250)\end{array}$ & & & $\begin{array}{c}0.0099 \\
(0.9443)\end{array}$ & & & $\begin{array}{c}0.0978 \\
(0.7957)\end{array}$ \\
\hline DeltaGDP & & & $\begin{array}{c}0.0220 \\
(0.3240)\end{array}$ & & & $\begin{array}{l}-0.1073 \\
(0.3956)\end{array}$ & & & $\begin{array}{c}0.6452 \\
(0.4317)\end{array}$ \\
\hline F-value (First Stage) & & 21.870 & 10.260 & & 20.850 & 23.850 & & 11.090 & 7.141 \\
\hline Adj. R2 & 0.135 & 0.191 & 0.192 & 0.074 & 0.172 & 0.183 & 0.168 & 0.133 & 0.286 \\
\hline No. of obs. & 25 & 25 & 25 & 22 & 22 & 22 & 22 & 22 & 22 \\
\hline
\end{tabular}

Notes: Robust clustered standard errors in parenthesis. ${ }^{* * *}$ indicates a significance level below 5 percent; ${ }^{* *}$ indicates significance level between 5 and 10 percent; ${ }^{*}$ indicates significance level between 10 and 15 percent. 
Table 5

Effect of high-skilled net emigration rates on various measures of public investment spending as fraction of GDP (IV only)

\begin{tabular}{|c|c|c|c|c|c|c|c|c|}
\hline & $\begin{array}{l}I V \\
(1)\end{array}$ & $\begin{array}{l}I V \\
(2)\end{array}$ & $\begin{array}{l}I V \\
(3)\end{array}$ & $\begin{array}{l}I V \\
(4)\end{array}$ & $\begin{array}{l}I V \\
(5)\end{array}$ & $\begin{array}{l}I V \\
(6)\end{array}$ & $\begin{array}{l}I V \\
(7)\end{array}$ & $\begin{array}{l}I V \\
(8)\end{array}$ \\
\hline \multirow[t]{2}{*}{ Dependent Variable } & Level of & Change in & Level of & Change in & Level of & Change in & Level of & Change in \\
\hline & \multicolumn{2}{|c|}{ PubInv-fraction } & \multicolumn{2}{|c|}{ R\&DTotal-fraction } & \multicolumn{2}{|c|}{ RひDHigherEdu-fraction } & \multicolumn{2}{|c|}{ ExpEdu-fraction } \\
\hline (Intercept) & $\begin{array}{c}0.0483^{* * *} \\
(0.0029)\end{array}$ & $\begin{array}{c}-0.1195^{* * *} \\
(0.0459)\end{array}$ & $\begin{array}{c}0.0196^{* * *} \\
(0.0019)\end{array}$ & $\begin{array}{c}0.2824^{* * *} \\
(0.0760)\end{array}$ & $\begin{array}{c}0.0041^{* * *} \\
(0.0003)\end{array}$ & $\begin{array}{c}0.3282^{* * *} \\
(0.0733)\end{array}$ & $\begin{array}{c}0.0609^{* * *} \\
(0.0025)\end{array}$ & $\begin{array}{c}0.0056 \\
(0.1083)\end{array}$ \\
\hline Mig & $\begin{array}{l}-0.0493^{*} \\
(0.0308)\end{array}$ & & $\begin{array}{c}-0.0247^{*} \\
(0.0169)\end{array}$ & & $\begin{array}{c}-0.0063^{* * *} \\
(0.0030)\end{array}$ & & $\begin{array}{l}-0.0087 \\
(0.0206)\end{array}$ & \\
\hline DeltaMig & & $\begin{array}{c}-1.8268^{* *} \\
(0.9292)\end{array}$ & & $\begin{array}{c}-4.3592^{* *} \\
(2.1723)\end{array}$ & & $\begin{array}{c}-3.9369^{* * *} \\
(1.5645)\end{array}$ & & $\begin{array}{l}-3.0307 \\
(2.6202)\end{array}$ \\
\hline F-value (First Stage) & 85.860 & 31.690 & 82.150 & 21.870 & 82.150 & 20.850 & 85.860 & 11.090 \\
\hline Adj. R2 & 0.138 & 0.124 & 0.151 & 0.177 & 0.058 & 0.175 & 0.040 & 0.031 \\
\hline No. of obs. & 25 & 22 & 30 & 25 & 30 & 22 & 25 & 22 \\
\hline
\end{tabular}

Notes: Robust clustered standard errors in parenthesis. ${ }^{* * *}$ indicates a significance level below 5 percent; ${ }^{* *}$ indicates significance level between 5 and 10 percent; ${ }^{*}$ indicates significance level between 10 and 15 percent. 
Table 6

Effect of gross high skilled immigration and emigration rates on public investment and changes in public investment (IV only)

\begin{tabular}{|c|c|c|c|c|c|c|c|c|}
\hline & $\begin{array}{l}I V \\
(1)\end{array}$ & $\begin{array}{l}I V \\
(2)\end{array}$ & $\begin{array}{l}I V \\
(3)\end{array}$ & $\begin{array}{l}I V \\
(4)\end{array}$ & $\begin{array}{l}I V \\
(5)\end{array}$ & $\begin{array}{l}I V \\
(6)\end{array}$ & $\begin{array}{l}I V \\
(7)\end{array}$ & $\begin{array}{c}I V \\
(8)\end{array}$ \\
\hline Dependent Variable & PubInv & ReDTotal & $\begin{array}{c}\text { Red } \\
\text { HigherEdu }\end{array}$ & $E x p E d u$ & DeltaPubInv & $\begin{array}{c}\text { DeltaRe } \infty \\
\text { Total }\end{array}$ & $\begin{array}{l}\text { DeltaReD } \\
\text { HigherEdu }\end{array}$ & $\begin{array}{c}\text { DeltaExp } \\
E d u\end{array}$ \\
\hline (Intercept) & $\begin{array}{c}11.2170^{* * *} \\
(1.8787)\end{array}$ & $\begin{array}{c}3.5810 \\
(4.2946)\end{array}$ & $\begin{array}{l}-0.0950 \\
(2.9806)\end{array}$ & $\begin{array}{c}2.9743^{* * *} \\
(0.9215)\end{array}$ & $\begin{array}{c}0.8044 \\
(0.7416)\end{array}$ & $\begin{array}{l}-0.3232 \\
(1.5287)\end{array}$ & $\begin{array}{c}0.0275 \\
(1.1887)\end{array}$ & $\begin{array}{c}-0.8312^{*} \\
(0.4908)\end{array}$ \\
\hline Immig & $\begin{array}{l}1.5195^{* *} \\
(0.7577)\end{array}$ & $\begin{array}{l}2.4075^{* *} \\
(1.4340)\end{array}$ & $\begin{array}{l}3.8819^{* * *} \\
(1.4295)\end{array}$ & $\begin{array}{l}1.6850^{* * *} \\
(0.5687)\end{array}$ & & & & \\
\hline Emig & $\begin{array}{l}-0.9996^{*} \\
(0.6253)\end{array}$ & $\begin{array}{l}-1.4683^{*} \\
(1.0085)\end{array}$ & $\begin{array}{l}-0.2527 \\
(1.2706)\end{array}$ & $\begin{array}{c}-1.0066^{* * *} \\
(0.4313)\end{array}$ & & & & \\
\hline DeltaImmig & & & & & $\begin{array}{c}0.3585^{*} \\
(0.2358)\end{array}$ & $\begin{array}{c}0.1860 \\
(0.1953)\end{array}$ & $\begin{array}{c}0.8896^{*} \\
(0.5628)\end{array}$ & $\begin{array}{c}0.2685 \\
(0.2363)\end{array}$ \\
\hline DeltaEmig & & & & & $\begin{array}{c}-0.1088^{*} \\
(0.0580)\end{array}$ & $\begin{array}{c}-0.3511^{*} \\
(0.2282)\end{array}$ & $\begin{array}{l}-0.4791 \\
(0.6043)\end{array}$ & $\begin{array}{c}-0.7717^{*} \\
(0.4567)\end{array}$ \\
\hline Pop & $\begin{array}{l}-0.1148 \\
(0.0897)\end{array}$ & $\begin{array}{l}-0.0640 \\
(0.1206)\end{array}$ & $\begin{array}{c}0.2193 \\
(0.2131)\end{array}$ & $\begin{array}{c}0.0004 \\
(0.0282)\end{array}$ & & & & \\
\hline Рор16 & $\begin{array}{c}-0.0889^{* * *} \\
(0.0350)\end{array}$ & $\begin{array}{l}-0.0557 \\
(0.0405)\end{array}$ & $\begin{array}{c}-0.0628^{* *} \\
(0.0327)\end{array}$ & $\begin{array}{c}0.0979^{* * *} \\
(0.0201)\end{array}$ & & & & \\
\hline SocialExp & $\begin{array}{c}-0.2421^{* *} \\
(0.1273)\end{array}$ & $\begin{array}{c}0.4768 \\
(0.3787)\end{array}$ & $\begin{array}{c}0.3617 \\
(0.2922)\end{array}$ & $\begin{array}{c}0.2958^{* * *} \\
(0.0762)\end{array}$ & & & & \\
\hline DeltaPop & & & & & $\begin{array}{c}-1.4834^{* * *} \\
(0.7012)\end{array}$ & $\begin{array}{c}0.6219 \\
(1.6578)\end{array}$ & $\begin{array}{c}0.0620 \\
(1.2381)\end{array}$ & $\begin{array}{l}-0.3171 \\
(0.4144)\end{array}$ \\
\hline DeltaGDeP & & & & & $\begin{array}{c}0.7657^{* * *} \\
(0.2018)\end{array}$ & $\begin{array}{c}0.2269 \\
(0.4289)\end{array}$ & $\begin{array}{c}0.4594 \\
(0.4807)\end{array}$ & $\begin{array}{c}1.1754^{* * *} \\
(0.2233)\end{array}$ \\
\hline F-value First Stage (Delta)Immig & 24.740 & 33.980 & 33.980 & 23.750 & 26.590 & 26.640 & 45.560 & 18.580 \\
\hline F-value First Stage (Delta)Emig & 46.820 & 53.370 & 53.370 & 81.540 & 42.080 & 12.430 & 18.730 & 19.370 \\
\hline Adj. R2 & 0.249 & 0.247 & 0.123 & 0.618 & 0.273 & 0.051 & 0.082 & 0.245 \\
\hline No. of obs. & 22 & 30 & 30 & 25 & 22 & 25 & 22 & 22 \\
\hline
\end{tabular}

Notes: Robust clustered standard errors in parenthesis. Immig stands for the immigration rate of high skilled and Emig denotes the emigration rate of high skilled. DeltaImmig and DeltaEmig represent changes of immigration and emigration rates from 1990 to 2000 respectively. ${ }^{* * *}$ indicates a significance level below 5 percent; ${ }^{* *}$ indicates significance level between 5 and 10 percent; ${ }^{*}$ indicates significance level between 10 and 15 percent. 


\title{
Authors
}

\section{Volker GROSSMANN}

University of Fribourg; CESifo, Munich; and Institute for the Study of Labor (IZA), Bonn. Postal adress: University of Fribourg, Department of Economics, Bd. de Pérolles 90, G424, 1700 Fribourg,Switzerland. Tel.: +41 (0)26 3009383. Email: volker.grossmann[at]unifr.ch

\section{David STADELMANN}

University of Fribourg, Department of Economics, Bd. de Pérolles 90, F410, 1700 Fribourg, Switzerland. Tel.: +41 (0)26 3009382. Email: david.stadelmann[at]unifr.ch

\begin{abstract}
This paper analyzes the interaction between migration of high-skilled labor and publicly financed investment. We develop a theoretical model with multiple, ex ante identical jurisdictions where individuals decide on education and subsequent emigration.

Migration decisions are based on differences in net income across jurisdictions which endogenously may occur. The interaction between income differences and migration flows gives rise to the potential of multiple equilibria: a symmetric equilibrium without migration and an asymmetric equilibrium in which net income levels differ among jurisdictions and trigger migration flows.

In the former equilibrium, all jurisdictions have the same public investment level.

In the latter one, public investment is high in host economies of skilled expatriates and low in source economies. We empirically test the hypothesis that emigration rates are negatively associated with various kinds of publicly .nanced investment levels for OECD countries.
\end{abstract}

\section{Keywords}

High-skilled migration; Human capital externalities; Publicly financed investment

\section{JEL Classification}

$\mathrm{F} 22, \mathrm{H} 40$

\section{Citation proposal}

Grossmann Volker, Stadelmann David. 2010. «Does High-Skilled Migration Affect Publicly Financed Investments?». Working Papers SES 413, Faculty of Economics and Social Sciences, University of Fribourg (Switzerland)

\section{Working Papers SES}

Last published :

408 Dumont P.-A., Isakov D.: Les rachats d'actions en Suisse. Objectifs, conséquences et pratiques; 2009

409 Friboulet J.-J.: Attractivité et économie géographique : une première approche, 2009

410 Biwolé Fouda, J.: Privatisation des Industries de Réseaux et développement durable : le cas du Cameroun; 2010

411 Friboulet J.-J.: La théorie néoclassique et le développement durable; 2010

412 Rohe A., Grünig R.: Strategie unter Unsicherheit; 2010

\section{Catalogue and download links:}

http://www.unifr.ch/ses/wp

http://doc.rero.ch/collection/UNIFR WORKING PAPERS SES 